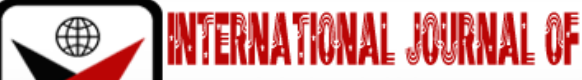

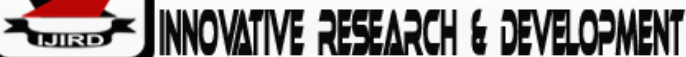

ISSN 2278-0211 (Online)

\section{Adequacy of Exposure of Entrepreneurship Skills in Business Education Programme for Graduates of Tertiary Institutions in Taraba State, Nigeria}

\begin{tabular}{c}
\hline Joseph Yaro Tunga \\
Senior Lecturer, Department of Business Education, \\
University of Nigeria, Nsukka, Nigeria \\
Hosea, Idihwere ,Danfulanj \\
Lecturer, Department of Business Education, College of Education, \\
Kwararafa University, Wukari, Nigeria
\end{tabular}

\begin{abstract}
:
This study centred on determining the adequacy of exposure of entrepreneurship skills in Business Education programme for graduates of tertiary institutions in Taraba State, Nigeria. The study adopted a descriptive survey design. A 50-item structured questionnaire was used to collect data from 122 business education lecturers and students from three tertiary institutions in Taraba State that offer business education programme. The questionnaire was face validated by three experts. Two of the experts were from the University of Nigeria, Nsukka while one was from Taraba State University. The results of the study showed that the entrepreneurship skills are not adequately exposed in business education programmes in tertiary institutions and thus making it difficult for students to graduate with the $21^{\text {st }}$ century skills needed for employment in today's world of work. Some of the problems militating against adequate exposure of entrepreneurship skills in business education programme is the curriculum inclusiveness, lecturers lack of entrepreneurship skills and inadequate provision of the 21 st century state-of-the-art technological equipment. Based on the findings, it was recommended among others that government should strive to infuse policies that are relevant for effective integration of entrepreneurship skills into the National Policy on Education, and that the business education curriculum should be reviewed and updated to include entrepreneurship skills both in content and pedagogy. The paper submits that all relevant stake holders should realise that except students are adequately trained with the $21^{\text {st }}$ Century skills, they will not be able to compete effectively in the labour market and be self-reliance.
\end{abstract}

Keywords: Entrepreneurship, skills, adequacy of exposure, business education

\section{Introduction}

Nigeria`s struggle to create jobs is getting worse, the recent data published by national Bureau of Statistic (NBS) pegs the unemployment rate at $18.8 \%$ in the third quarter of 2017 , to $23.1 \%$ in the third quarter of 2018 , this implies that it is rather increasing than decreasing. Another aspect of the unemployment problem is the over dependence on Government for white collar job. Due to the magnitude of this problem, it has trigger up the greatest concern for the graduate and school leavers who are on the increase without a corresponding Jobs available to absorb them. They enter the labour market in search of jobs that do not exist. In order to draw the majority of the jobless out of this, there was the need to provide them with business education early in their career in schools. Business education is a part of general education that prepares students for entry into the world of work and advancement within business. It equally prepares students to handle their own business affairs in order to function intelligently as consumers and citizens in a business economy. Azuka (2000) defines business education as a programme of studies which aims at creating awareness in business occupation, preparing youths for work in business occupation, preparing people to become better citizens and consumers of goods, services and preparing business teachers. Unfortunately, vocational technical education which include business education according to Osuala (2009) has not been able to solve this problem. Hence the need to integrate entrepreneurship courses into business education programme since entrepreneurship education will provide additional skills, resources and methodologies to business education graduate and viable businesses after graduating from their schools, making them employers of labour and not seekers of labour. Any person who engages in carrying out any business activity related to commercial or industrial purpose is an entrepreneur. Some real-life examples of such entrepreneurs in Nigeria and the world are: AligoDangote (founder of dangote group of companies) Bill Gates (founder of Microsoft) Mark Zuckerberg (founder of facebook and Larry Page (founder of Google etc.). An entrepreneur is a risk bearer since he co-ordinate the other factors of production; he bears the profit or loses of the business. Aminu (2009) looked at an 
enterprise as a business that has been set up by an individual or group of individuals for a certain purpose. The purpose is to make profit from business enterprise or promoting social interest which could be a public enterprise.

Addressing the high rate of unemployment should begin with the change of mind set of citizens, diversification of our economic base and reformed in our educational sector especially in the programmes of business education since the main purpose of business education is equipping its recipients with practical skills and values to become self-reliant and to be employable in the labour markets, Business education should be reformed with a focus on entrepreneurship skill so that it will adopt a system that will go side by side with skill acquisition just like other developed nations. The American Association of Colleges for Teacher Education, (AACTE) (2010) observed that for students of tertiary institutions to be prepared adequately for today's world of work, their training and what they are to learn must go beyond ordinary mastering of core subjects but must include 21st century knowledge and skills such as critical thinking, technology literacy, collaboration and communication.

Researches have shown that several schools have failed in preparing their students for the world of work particularly in the present knowledge economy (Morrison, 2010). Authors asked whether school systems need to be reformed to ensure that students are taught what they need to work in today's world of work? However, Trilling and Fadel (2010) noted that educational institutions have already an established building blocks to meet up with the 21 century skills requirements of the students. The authors added that what the institutions require is to give their students the needed skills for working in a complex and connected world.

Today's business world requires that students should be equipped with entrepreneurial skills such as critical thinking, technology literacy, collaboration and communication (AACTE, 2010; Trilling \&Fadel, 2010). Trilling and Fadel (2010) argued that success in today's world of work requires that the students should be exposed to both the traditional core competencies and also the 21st century skills that include: learning and innovation which has root in critical thinking, problem solving, creativity and innovation; digital literacy such as information, media, and technology literacy; and also life and career that include leadership, adaptability, initiative and self-direction, as well as accountability. Again, Trilling and Fadel (2010) lamented that following the global shift in economic trend from industrial age economy (industrial era where major jobs were in manufacturing, agriculture, construction) to a knowledge economy that educational institutions have failed to kept up to the job requirement of this shift. The authors maintained that students must be prepared to work, collaborate, solve problems, lead, follow, and create value. Furthermore, Morrison (2010) contend that the 21st Century Skills, are very essential to ensuring that business students do not enter the world of work or join the work force as people who are mindless and cannot contribute to the success of the business world and the economy. Instead, students should be prepared and equipped with the competencies to be independent and able to launch great ideas and initiatives of their own and take initiatives. This can be achieved through the integration of 21st Century entrepreneurial skills in every aspect of business programme. The 21st Century Skills entrepreneurial skills prepares students to be leaders, innovators and possibly captains of industry and economic decision makers (Trilling \&Fadel, 2010; Morrison, 2010). According to a survey by the American Management Association AMA (2010) entrepreneurial skills such as communication, critical thinking/problem solving, creativity, collaboration/teamwork, interpersonal skills, critical thinking, problem solving and teamwork are very necessary skills students require for post-graduate entry-level employment.

Taking into cognisance that un employment among others is due to low productivity index. The Federal government of Nigeria in 1986 set up National Directorate of Employment (NDE) with the aim of addressing the alarming rate of unemployment especially among graduates and school leavers and that the best way of addressing this menace is by assisting the young ones with facilities to own their businesses. Entrepreneurship Development programme was set up with the following aims to: stimulate self-employment for unemployed youth, train and produce entrepreneurs that are needed for the current challenges, expand economic activities, and encourage Nigerians to change from a consuming nation to exporting nation.

The uncontrollable rate of unemployment and poverty should bring about the dire need to carrying out the modification in business education programme in Nigeria so that graduate will not only be exposed to particular skills such as marketing, Accounting and office technology and Management (O.T.M) but also to be creative thinking sufficiently enough, to establish and run or own a business at least at a small-scale level. In other words, making students more of employers of labour than job seekers, now that the nation's economy is dwelling in what is called economic meltdown. This cannot be achieved except by a deliberate modification in the curriculum of business education to include entrepreneurship courses that will train the students to become productive citizens and not only intelligent consumers. Such entrepreneurial courses ought to include: invention and patents, building and leading effective team, organizational leadership and change, managing the innovation: emerging trends, how to develop breakthrough product and service, software business, seminar in corporate entrepreneurship, entrepreneurial sales, global entrepreneurship lab, new enterprise capital, laws for the entrepreneur and manager, field trip, project, apprenticeship, and industrial attachment among others.

In order to be at par with developed and developing nations of the world, the above courses are geared towards making the students ventures creators apart from articulating artisans and the non-formals, making it clear to the students that these set of people are entrepreneurs who are directly or indirectly contributing to the GDP of the State. I am sure that business education will play a more significant role in Nigerian economic growth and development. It will also improve personal qualities and build more positive attitudes that will be necessary for adjustment to personal and employment situation and will also provide more knowledge, skill and competence for individual graduate to function well as both entrepreneurs and in office occupation that will create job for themselves and others thereby solving the unemployment problems. 
Entrepreneurship businesses are available in all aspects of human endeavour including, entertainment, mining and agriculture, manufacturing and construction services, occupation and distribution industry. To get Nigeria out of this menace and keep the economy moving on the road to sustainable growth, with fairness, the nation will need to take stock of the past experiences, consider the present emerging challenges and focus on the positive future by articulating entrepreneurship courses into business education programmes. Entrepreneurship is the ability and willingness of an individual to seek investment opportunities, establish and run an enterprise successfully. Timmons in Sherief (2005) described entrepreneurship as the ability to create and build wealth from practically nothing while Kuratka and Richard (2001) defined entrepreneurship as a dynamic process for job and wealth creation. Wealth creation is the discovery and development of resources as well as assets creatively and innovatively. Kelly and Norwood (2011) stated that rural wealth creation is the valuing of natural resources that form the base of rural communities in new ways to create rising demands for forest stewardship, organic agriculture, sustainable fisheries, renewable energy, wastelands restoration, land conservation and carbon sequestration. Wealth can also be created by combining materials, labour, land and technology that are available in the community to capture a profit (Smith, 2005).

\subsection{Statement of the Problems}

The introduction of business education programme in the institutions to equip graduates and make them selfreliance without adequately imparting entrepreneurship skills in Taraba State institutions will still lead to lack of the acquisition of the knowledge and skills expected to prepare the graduates for the world of work and to be venture creators. Azuka (2006) correctly pointed out that curriculum should be based upon the needs and interest of the students, the community and the entire society. Business education curriculum that will best meet the needs of graduates should be introduced. Therefore, this study is to find out the adequacy of entrepreneurship skills in business education programme to meet up with the emerging challenges of unemployment in Taraba State, Nigeria

\subsection{Purpose of Study}

The purpose of this study is to assess the adequacy of entrepreneurship skill in the business education programmes in tertiary institutions in Taraba State. Specifically, the study sought to find out the:

- Adequacy of innovation skills in the business education programme in Taraba State tertiary institutions.

- Adequacy of qualified personnel for teaching business education programmes in tertiary institutions in Taraba State?

- Adequacy of critical and creative thinking skills in business education programmes in Taraba State tertiary institutions.

- Adequacy of equipment available for business education programmes in Taraba State tertiary institutions.

\subsection{Research Questions}

The following research questions guided the study:

- How adequate are skill acquisition programmes in business education programmes in tertiary institutions in Taraba State?

- How adequate are innovation skill in the business education programmes in tertiary institutions in Taraba State?

- Are there adequate and qualified personnel for the teaching of business education programmes in tertiary institutions in Taraba State?

- How adequate are the critical and creative thinking skills in business education programmes in tertiary institutions in Taraba State?

- Are there adequate equipments for business education programmes in tertiary institutions in Taraba State?

\subsubsection{Hypothesis}

- $\mathrm{Ho}_{1}$ : There is no significant difference in the mean responses of lecturers and students on the adequacy of skills acquisition courses in business education programmes in Taraba State tertiary institutions.

- $\mathrm{Ho}_{2}$ : There is significant difference in the mean responses of lectures and students on the adequacy of skill acquisition course in business education programmes in tertiary institutions in Taraba State.

- $\mathrm{Ho}_{3}$ : There is no significant difference on the mean responses of lecturers and students on the adequacy of personnel for lecturing in business education programmes in tertiary institutions in Taraba State.

\section{Methodology}

The population for the study comprised 22 lecturers of business education programmes of tertiary institutions of Taraba State and 100 graduating students of business education programmes of the tertiary institutions in Taraba State. The entire population was studied. Hence there was no sample and sampling technique because the population was manageable. The study was delimited to the adequacy of exposure of entrepreneurship skills for business education programmes for graduate of tertiary institutions in Taraba State. Data was collected through the use of structured questionnaire which consisted two section; A and B, the first section sought the demographic data of the respondents while the second section consisted of 50 items with four-point rating scale of very adequate (5), adequate (4), Fairly adequate (3), and inadequate (1). Copies of the questionnaire were distributed personally and out of the 122 copies distributed 118 copies were retrieved representing 96\% returns. Mean statistics was used to answer the research questions and t-test to test the hypotheses at 0.05 level of significance. The null hypotheses were not rejected if the 
calculated t-value is less than the critical t-value but if the calculated $t$-value is equal or greater than the critical t-value, the null hypotheses will be rejected.

\section{Results}

\subsection{Research Question One}

How adequate are skill acquisition programmes in business education programmes in tertiary institutions in Taraba State?

\begin{tabular}{|c|c|c|c|c|}
\hline $\mathbf{S} / \mathbf{N}$ & Item Statement. Ability to: & \multicolumn{2}{|c|}{$\mathrm{X} \quad \mathrm{SD}$} & Remarks \\
\hline 1 & keep going in the face of hardship & 2.26 & 0.76 & IA \\
\hline 2 & raise money & 2.34 & 0.58 & $"$ \\
\hline 3 & be productive & 2.39 & 0.85 & $"$ \\
\hline 4 & making entrepreneurship & 2.17 & 0.66 & $"$ \\
\hline 5 & identify strength \& weakness & 2.43 & 0.48 & $"$ \\
\hline 6 & hiring effective people & 1.96 & 0.75 & $"$ \\
\hline 7 & relieve stress & 2.28 & 0.92 & $"$ \\
\hline 8 & train new staff & 2.40 & 0.96 & $"$ \\
\hline 9 & Risk Tolerance & 2.14 & 0.71 & $"$ \\
\hline 10 & Resilience & 2.22 & 0.59 & $"$ \\
\hline & Overall & 2.25 & 0.73 & IA \\
\hline
\end{tabular}

Table 1: Mean Ratings and Standard Deviation of Respondents on the Adequacy of

Skill Acquisition Programmes in Business Education Programmes in Tertiary Institutions in Taraba State?

$$
N=118
$$

$$
\text { Key: } \overline{\mathrm{X}}=\text { Mean; } S D=\text { Standard Deviation } ; A=\text { adequate } ; A=\text { Inadequate }
$$

The data presented in Table 1 indicated that ten (10) items which their mean ranged from 1.96 to 2.43 with standard deviation ranging from 0.48-0.96 are implemented to inadequacy of the skills in business education programmes. The overall mean of 2.25 indicated that all the items were not adequately inculcated in business education programme. This implies that all the respondents were in agreement that all the items in the table are not adequately incorporated into business education programme. The standard deviations of each of the items as well as the overall standard deviation stated above implied that the opinions of all the respondents are closely together that there is inadequacy of skill acquisition programmes in the business education programme tertiary institutions in Taraba State.

\subsection{Research Question Two}

How adequate are innovation skill in the business education programmes in tertiary institutions in Taraba State?

\begin{tabular}{|c|c|c|c|c|}
\hline S/N & Item Statement. Ability to & $\overline{\mathbf{X}}$ & SD & Remarks \\
\hline 1 & Adequacy of managing staff & 2.26 & 0.67 & IA \\
\hline 2 & Adequate ability to A/B Splite test & 2.17 & 0.66 & " \\
\hline 3 & $\begin{array}{c}\text { Adequate ability to connect via } \\
\text { social networking }\end{array}$ & 2.43 & 0.48 & " \\
\hline 4 & $\begin{array}{c}\text { Adequate ability to focus on your } \\
\text { customers }\end{array}$ & 1.96 & 0.75 & " \\
\hline 5 & Adequate ability to close a sale & 2.28 & 0.92 & $"$ \\
\hline 6 & Adequate ability to spot new trends & 2.34 & 0.58 & " \\
\hline 7 & Adequate ability to deal with failure & 2.40 & 0.96 & IA \\
\hline & Overall & 2.26 & 0.72 & . \\
\hline
\end{tabular}

Table 2: Mean Ratings and Standard Deviation of Respondents on the Adequacy of Innovation Skill in Business Education Programmes in Tertiary Institutions in Taraba State?

$$
N=118
$$

Key: $\overline{\mathrm{X}}=$ Mean, $S D=$ Standard Deviation, $A$ = adequate, $I A=$ Inadequate

The data presented in Table 2 indicate that the respondents agree that all the innovation skills presented with the mean ranging from $1.96-2.43$ are not adequately taught in business education programme. The standard deviation of each item and the overall standard deviation ranged from 0.48-0.98, which implies that all the respondents have similar opinions that all the items presented in the Table 2 are not adequately taught in business education programmes.

\subsection{Research Question Three}

Are there adequate personnel for lecturing in business education programmes in tertiary institutions in Taraba State? 


\begin{tabular}{|c|c|l|l|l|}
\hline $\mathbf{S} / \mathbf{N}$ & Item Statement & $\overline{\mathbf{X}}$ & $\mathbf{S D}$ & Remarks \\
\hline 1 & Lecturers & 2.49 & .69 & IA \\
\hline 2 & Instructors & 2.29 & .64 & " \\
\hline 3 & $\begin{array}{c}\text { Lecturers with entrepreneurship } \\
\text { skills }\end{array}$ & 1.66 & .88 & " \\
\hline 4 & $\begin{array}{c}\text { Instructors with entrepreneurship } \\
\text { skills }\end{array}$ & 1.59 & .86 & " \\
\hline 5 & Lecturers who are ICT compliant & 2.36 & .74 & " \\
\hline 6 & Instructors who are ICT compliant & 2.40 & .71 & " \\
\hline 7 & Lab technicians & 2.20 & .79 & " \\
\hline & Data annalists & 2.18 & .81 & " \\
\hline 8 & Supporting staff & 1.58 & .87 & " \\
\hline & Overall & 2.08 & 0.78 & IA \\
\hline
\end{tabular}

Table 3: Mean Ratings and Standard Deviation of Respondents on the Adequacy of Personnel for Lecturing in Business Education Programmes in Tertiary Institutions in Taraba State?

$$
N=118
$$

Key: $\overline{\mathrm{X}}=$ Mean; $S D=$ Standard Deviation; $A$ = adequate IA = Inadequate

The data presented in Table 3 shows that all the items, have their mean ranged from $1.58-2.49$ with an overall mean of 2.26 which implies that the respondents agreed that there are inadequate staff for the teaching of business education courses in tertiary institutions in Taraba State. The low standard deviation for each of the eight items as well as the overall standard deviation which ranged from $0.69-0.88$ indicates that all the respondents have similar opinions that there is inadequate staff in business education programme.

\subsection{Research Question Four}

How adequate are the critical and creative thinking skills in business education programmes in tertiary institutions in Taraba State?

\begin{tabular}{|c|c|c|c|c|}
\hline $\mathbf{S} / \mathbf{N}$ & Item Statement. Adequate ability to: & $\overline{\mathbf{X}}$ & SD & Remarks \\
\hline 1 & Recognise opportunity & 1.49 & .79 & IA \\
\hline 2 & $\begin{array}{l}\text { Explore or examine business chances so as to make a } \\
\text { constructive diagnosis and find solutions. }\end{array}$ & 2.24 & .55 & " \\
\hline 3 & $\begin{array}{l}\text { Probe into new areas and interpreting, explaining and } \\
\text { making predictions. }\end{array}$ & 1.76 & .66 & " \\
\hline 4 & Reasoning and making logical conclusions & 1.39 & .86 & " \\
\hline 5 & Venture into producing new product. & 1.36 & .87 & " \\
\hline 6 & Improve on a driven opportunity. & 1.20 & .91 & " \\
\hline 7 & $\begin{array}{l}\text { Solve different kinds of non-familiar problems in both } \\
\text { conventional and innovative ways. }\end{array}$ & 1.46 & .81 & " \\
\hline 8 & $\begin{array}{l}\text { Effectively analyse and evaluate evidence, arguments, } \\
\text { claims and beliefs in real life situation. }\end{array}$ & 2.22 & .57 & " \\
\hline 9 & $\begin{array}{l}\text { Use a wide range of idea creation techniques to create } \\
\text { new and worthwhile ideas. }\end{array}$ & 1.65 & .72 & " \\
\hline 10 & $\begin{array}{c}\text { Elaborate, refine, analyse and evaluate one's own idea in } \\
\text { order to improve and maximize creative efforts. }\end{array}$ & 1.41 & .74 & “ \\
\hline 11 & $\begin{array}{l}\text { Analyse how parts of a whole interact with each other to } \\
\text { produce overall outcomes in complex systems. }\end{array}$ & 1.28 & .88 & " \\
\hline 12 & $\begin{array}{l}\text { Making and inferences using inductive and deductive } \\
\text { reasoning. }\end{array}$ & 1.29 & .87 & \\
\hline & Overall & 1.59 & 0.76 & IA \\
\hline
\end{tabular}

Table 4: Mean Ratings and Standard Deviation of Respondents on the Adequacy of Critical and Creative Thinking Skills in Business Education Programmes in Tertiary Institutions in Taraba State?

$$
N=118
$$

Key: $\overline{\mathrm{X}}=$ Mean $\boldsymbol{S D}=$ Standard Deviation $\boldsymbol{A}$ = adequate IA = Inadequate

The data presented in Table 4 shows that 12-items have their mean ranged from $1.20-2.24$ with an overall mean of 1.59 which implies that the respondents agreed that the critical and creative thinking skills identified are not adequately taught in business education programme. The standard deviation for the six items as well as the overall standard deviation which ranged from $0.55-0.91$ indicates that all the respondents have similar opinions that all the items in the Table are critical and creative thinking skills and these skills are not adequately taught in the business education programme. 


\subsection{Research Question Five}

Is there adequate equipment for business education programmes in tertiary institutions in Taraba State?

\begin{tabular}{|c|c|c|c|c|}
\hline $\mathbf{S} / \mathbf{N}$ & Item Statement & $\overline{\mathbf{X}}$ & $\mathbf{S D}$ & Remarks \\
\hline 1 & Computer & 2.74 & .84 & $\mathrm{~A}$ \\
\hline & Cyber café & 1.08 & .95 & $\mathrm{IA}$ \\
\hline 2 & e-mail & 2.53 & .81 & $\mathrm{~A}$ \\
\hline & Virtual realities equipment & 1.04 & .84 & " \\
\hline 3 & Cloud computing facilities & 1.14 & .90 & " \\
\hline 4 & Teleconferencing equipment & 1.69 & .91 & " \\
\hline 5 & Internet facilities & 2.52 & .52 & $\mathrm{~A}$ \\
\hline 6 & Uninterrupted power supply & 1.97 & .81 & " \\
\hline 7 & Printer & 2.53 & .96 & $\mathrm{~A}$ \\
\hline 8 & Projector & 2.07 & .98 & " \\
\hline 9 & Scanner base & 2.48 & .68 & " \\
\hline 10 & Modern & 2.77 & .74 & " \\
\hline 11 & Software packages (Apps) and social media & 2.13 & .90 & " \\
\hline 12 & Internet of Things (Io T) & 1.19 & .91 & " \\
\hline 13 & ipod, smartphone & 1.52 & .72 & " \\
\hline
\end{tabular}

Table 5: Mean Ratings and Standard Deviation of Respondents on the Adequacy of Equipment Available in Business Education Programmes in Tertiary Institutions in Taraba State

$$
N=118
$$

$$
\text { Key: } \overline{\mathrm{X}}=\text { Mean, } S D=\text { Standard Deviation, } A=\text { Adequate }, I A=\text { Inadequate }
$$

The data presented in Table 5 shows that items $2,4,6,8,9,10,11,12$, and 13 have their Mean ranged from $1.04-$ 2.48 , which implies that the respondents strongly agreed that those items are technological equipment required for teaching of entrepreneurship skills in tertiary institutions but unfortunately the equipment are not adequately used in the teaching of business education courses in Taraba State. The respondents were also in agreement that items 1, 3, 5, 7 with mean ranged from $2.52-2.77$ are used in the teaching of business education courses in tertiary institutions in Taraba State. The overall mean of 1.96, however, implies that all the respondents strongly agreed that the items in the Table are inadequately used in the teaching of business education courses in tertiary institutions Taraba State. The standard deviation for each of the 13 items as well as the overall standard deviation which ranged from 0.52 - 0.98 indicates that all the respondents have similar opinions that all the items in the Table are technological equipment required for the teaching of business education courses though most of them are not adequately used in the teaching of business education courses in tertiary institutions in Taraba State.

\subsection{Hypotheses}

\subsubsection{Hypothesis One}

There is no significant difference in the mean responses of lecturers and students on the adequacy of skills

\begin{tabular}{|c|c|c|c|c|c|c|c|c|c|}
\hline \multirow[t]{2}{*}{ S/NO } & \multirow[t]{2}{*}{$\begin{array}{l}\text { Item Statement } \\
\text { Ability to: }\end{array}$} & \multicolumn{2}{|c|}{$\begin{array}{c}\text { Bus. Edu } \\
\text { Lecturers }\end{array}$} & \multicolumn{2}{|c|}{$\begin{array}{l}\text { Bus. Edu } \\
\text { students }\end{array}$} & \multirow[t]{2}{*}{ Df } & \multirow[t]{2}{*}{ t-cal } & \multirow[t]{2}{*}{$\begin{array}{c}\text { Sig. } \\
\text { 2-tailed }\end{array}$} & \multirow[t]{2}{*}{ Remarks } \\
\hline & & $\mathbf{X}_{1}$ & $\mathrm{SD}_{1}$ & $\mathbf{X}_{2}$ & $\mathbf{S D}_{2}$ & & & & \\
\hline 1 & $\begin{array}{l}\text { keep going in the face of } \\
\text { hardship }\end{array}$ & 3.23 & .83 & 3.12 & .84 & 116 & .62 & .95 & NS \\
\hline 2 & raise money & 3.05 & 1.08 & 3.08 & .92 & 116 & .93 & .34 & NS \\
\hline 3 & be productive & 2.17 & 1.01 & 2.00 & .76 & 116 & .42 & .07 & NS \\
\hline 4 & $\begin{array}{c}\text { generate } \\
\text { entrepreneurship ideas }\end{array}$ & 3.29 & .70 & 2.59 & 1.06 & 116 & .01 & .17 & $\mathrm{~S}$ \\
\hline 5 & $\begin{array}{c}\text { identify strength \& } \\
\text { weakness }\end{array}$ & 3.00 & .87 & 3.16 & .91 & 116 & .51 & .61 & NS \\
\hline 6 & hiring effective people & 3.47 & .62 & 3.12 & .95 & 116 & .15 & .09 & NS \\
\hline 7 & relieve stress & 3.47 & .62 & 3.52 & .50 & 116 & .73 & .06 & $\mathrm{~S}$ \\
\hline 8 & train new staff & 2.11 & .99 & 1.93 & .76 & 116 & .48 & .11 & NS \\
\hline 9 & risk tolerance & 2.47 & 1.12 & 2.05 & .90 & 116 & .18 & .06 & NS \\
\hline 10 & $\begin{array}{l}\text { resilience when faced with } \\
\text { challenged situation }\end{array}$ & 2.05 & 1.14 & 2.06 & 1.04 & 116 & .98 & .55 & NS \\
\hline
\end{tabular}
acquisition courses in business education programmes in tertiary institutions in Taraba State.

Table 6: t-test Analysis for Comparing Data Obtained from Lecturers and Students of on the Adequacy of Skills Acquisition Courses in Business Education Programmes in Tertiary Institutions in Taraba State 
Table 6 presents the t-test analysis of the business education lecturers and students mean ratings on the adequacy of skills acquisition courses in business education programmes in tertiary institutions in Taraba State. The analysis shows that the corresponding p-values to the t-values on each of the items in the Table ranged from 0.06-0.95, which are greater than 0.05 criterion level of significance. Hypothesis one $\left(\mathrm{HO}_{1}\right)$ with regard to those items was, therefore, not rejected because there was no significant difference between the mean ratings of the lecturers and students.

\subsubsection{Hypothesis Two}

There is significant difference in the mean responses of lectures and students on the adequacy of skill acquisition course in business education programmes in tertiary institutions in Taraba State.

\begin{tabular}{|c|c|c|c|c|c|c|c|c|c|}
\hline \multirow[t]{2}{*}{ S/NO } & \multirow[t]{2}{*}{ Item Statement } & \multicolumn{2}{|c|}{$\begin{array}{l}\text { Bus. Edu } \\
\text { Lecturers }\end{array}$} & \multicolumn{2}{|c|}{$\begin{array}{l}\text { Bus. Edu } \\
\text { Students }\end{array}$} & \multirow[t]{2}{*}{ Df } & \multirow[t]{2}{*}{ t-cal } & \multirow[t]{2}{*}{$\begin{array}{c}\text { Sig. } \\
\text { 2-tailed }\end{array}$} & \multirow[t]{2}{*}{ Remarks } \\
\hline & & $\mathbf{X}_{1}$ & $\mathrm{SD}_{1}$ & $\mathbf{X}_{2}$ & $\mathrm{SD}_{2}$ & & & & \\
\hline 1 & $\begin{array}{l}\text { Adequate ability to recognise } \\
\text { opportunity. }\end{array}$ & 3.23 & .83 & 3.12 & .84 & 116 & .62 & .95 & NS \\
\hline 2 & Adequate ability to explore. & 3.05 & 1.08 & 3.08 & .92 & 116 & .93 & .34 & NS \\
\hline 3 & $\begin{array}{l}\text { Adequate ability to probe into } \\
\text { new areas. }\end{array}$ & 2.17 & 1.01 & 2.00 & .76 & 116 & .42 & .07 & NS \\
\hline 4 & $\begin{array}{l}\text { Adequate ability to problem } \\
\text { solving. }\end{array}$ & 3.29 & .70 & 2.59 & 1.06 & 116 & .01 & .06 & $\mathrm{~S}$ \\
\hline 5 & $\begin{array}{l}\text { Adequate ability to venture } \\
\text { into producing new product. }\end{array}$ & 3.00 & .87 & 3.16 & .91 & 116 & .51 & .61 & NS \\
\hline 6 & $\begin{array}{c}\text { Adequate ability on } \\
\text { improvement driven } \\
\text { opportunity. }\end{array}$ & 3.47 & .62 & 3.12 & .95 & 116 & .15 & .09 & NS \\
\hline 7 & $\begin{array}{l}\text { Ability to solve different } \\
\text { kinds of non-familiar } \\
\text { problems in both } \\
\text { conventional and innovative } \\
\text { ways. }\end{array}$ & 3.47 & .62 & 3.52 & .50 & 116 & .73 & .13 & $\mathrm{~S}$ \\
\hline 8 & $\begin{array}{l}\text { Ability to effectively analyze } \\
\text { and evaluate evidence, } \\
\text { arguments, claims and beliefs } \\
\text { in real life situation. }\end{array}$ & 2.11 & .99 & 1.93 & .76 & 116 & .48 & .11 & NS \\
\hline 9 & $\begin{array}{c}\text { Ability to use } \\
\text { use a wide range of idea } \\
\text { creation techniques to create } \\
\text { new and worthwhile ideas. }\end{array}$ & 2.47 & 1.12 & 2.05 & .90 & 116 & .18 & .26 & NS \\
\hline 10 & $\begin{array}{l}\text { Being able to } \\
\text { elaborate, refine, analyse and } \\
\text { evaluate one's own ideas in } \\
\text { order to improve and } \\
\text { maximize creative efforts. }\end{array}$ & 2.05 & 1.14 & 2.06 & 1.04 & 116 & .98 & .55 & NS \\
\hline 11 & $\begin{array}{l}\text { Ability to analyze how parts } \\
\text { of a whole interact with each } \\
\text { other to produce overall } \\
\text { outcomes in complex systems }\end{array}$ & 3.11 & .99 & 3.55 & .53 & 116 & .096 & .31 & S \\
\hline
\end{tabular}

Table 7: t-test Analysis for Comparing Data Obtained from Lectures and Students on the Adequacy of Critical and Creative Thinking Skills in Business Education Programmes in Tertiary Institutions in Taraba State

Table 7 presents the t-test analysis of the lectures and students on the adequacy of critical and creative thinking skills in business education programmes in tertiary institutions in Taraba State. The analysis shows that the corresponding p-values to the t-values on each of the items in the Table except item 11 ranged from $0.70-0.95$, which are greater than 0.05 criterion level of significance. Hypothesis two (H02) with regard to those items was, therefore, not rejected because there was no significant difference between the mean ratings of the lectures and students.

\subsubsection{Hypothesis Three}

There is no significant difference on the mean responses of lecturers and students on the adequacy of personnel for lecturing in business education programmes in tertiary institutions in Taraba State. 


\begin{tabular}{|c|c|c|c|c|c|c|c|c|c|}
\hline \multirow[t]{2}{*}{ S/NO } & \multirow[t]{2}{*}{ Item Statement } & \multicolumn{2}{|c|}{$\begin{array}{l}\text { Bus. Edu } \\
\text { Lecturers }\end{array}$} & \multicolumn{2}{|c|}{$\begin{array}{l}\text { Bus. Edu } \\
\text { students }\end{array}$} & \multirow[t]{2}{*}{ Df } & \multirow[t]{2}{*}{ t-cal } & \multirow{2}{*}{$\begin{array}{c}\text { Sig. } \\
2- \\
\text { tailed }\end{array}$} & \multirow[t]{2}{*}{ Remarks } \\
\hline & & $X_{1}$ & $\mathrm{SD}_{1}$ & $X_{2}$ & $\mathrm{SD}_{2}$ & & & & \\
\hline 1 & Lecturers & 3.23 & .83 & 3.12 & .84 & 116 & .62 & .95 & NS \\
\hline 2 & Instructors & 3.05 & 1.08 & 3.08 & .92 & 116 & .93 & .34 & NS \\
\hline 3 & $\begin{array}{c}\text { Lecturers with } \\
\text { entrepreneur- ship skills }\end{array}$ & 2.17 & 1.01 & 2.00 & .76 & 116 & .42 & .07 & NS \\
\hline 4 & $\begin{array}{c}\text { Instructors with } \\
\text { entrepreneur- ship skills }\end{array}$ & 3.29 & .70 & 2.59 & 1.06 & 116 & .01 & .06 & S \\
\hline 5 & $\begin{array}{c}\text { Lecturers who are ICT } \\
\text { compliant }\end{array}$ & 3.00 & .87 & 3.16 & .91 & 116 & .51 & .61 & NS \\
\hline 6 & $\begin{array}{l}\text { Instructors who are ICT } \\
\text { compliant }\end{array}$ & 3.47 & .62 & 3.12 & .95 & 116 & .15 & .09 & NS \\
\hline 7 & Lab technicians & 3.47 & .62 & 3.52 & .50 & 116 & .73 & .08 & $S$ \\
\hline 8 & Supporting staff & 2.11 & .99 & 1.93 & .76 & 116 & .48 & .11 & NS \\
\hline
\end{tabular}

Table 8: T-Test Analysis for Comparing Data Obtained from Lecturers and Students on the Adequacy of Personnel for Lecturing In Business Education Programmes in Tertiary Institutions in Taraba State

Table 8 presents the t-test analysis of the business education lecturers and students' ratings on the on the adequacy of personnel for lecturing in business education programmes in tertiary institutions in Taraba State. The analysis shows that the corresponding p-values to the t-values on each of the items in the Table ranged from $0.60-0.95$, which are greater than 0.05 criterion level of significance. Hypothesis three (Ho3) with regard to those items was, therefore, not rejected because there was no significant difference between the mean ratings of the lecturers and students.

\section{Discussion}

The implementation of entrepreneurship skills in business education programme in tertiary institutions in Taraba State as revealed by this study is low. For instance, learning and innovation, critical thinking, problem solving, creativity and innovation, digital literacy, information, media and technology literacy, life and career initiative and self-direction, leadership, adaptability and accountability skills required by the business education students for employment in postgraduation are not provided adequately in business education programme. Again, it was revealed by the study that the business education has not incorporated into its academic programme the entrepreneurial skills that can equip business students with $21^{\text {st }}$ century business skills. As a result of this deficiency in providing the needed entrepreneurship skills, business students are not exposed to entrepreneurship skills. Such skills include the ability to: keep going in the face of hardship, raise business capital, be productive, generate entrepreneurship ideas, identify strength \& weakness, hire effective people, and relieve stress, train new staff, risk tolerance, and show resilience when faced with challenged situation. This finding is in agreement with Trilling and Fadel (2010) who lamented that following the global shift in economic trend from industrial age to a knowledge economy that educational institutions have not kept up to the job requirement current knowledge era economy. The finding of the study also validates AACTE (2010) who pointed out that some of the entrepreneurship skills required by business students for today's world of work include: learning and innovation, digital literacy, information, media and technology literacy, life and career initiative and self-direction, leadership, adaptability and accountability skills.

In addition, the study revealed that business education students in tertiary institutions in Taraba State are not adequately exposed to innovation skill that can help them excel economically in the current knowledge era. Some of the innovative skills include adequate ability to: manage staff, a/b sp lite test, connect via social networking, focus on your customers, close a sale, spot new trends, and deal with failure. This finding is congruent with Trilling and Fadel (2010) who emphasized that educational institutions can in addition to transferring the traditional skills to the students also equip them with the $21^{\text {st }}$ century skills like innovative skills which has root in critical thinking, problem solving, creativity and innovation. Again, the finding of this study on the inadequacy of innovation skills in business education programme concurred with Oosterbeek, Van Praag, and Ijsselstein (2010) who postulated that developing entrepreneurial mindset in the students will help them to adjust and have early vocational and entrepreneurial focus and capacity before entering the world of work. The finding also strengthened the view of AACTE (2010) that business education programme can be made effective if the training of the students involves innovative learning methods that support the integration and use of supportive technologies, inquiry and problem-based approaches as well as higher order thinking skills.

Furthermore, the study revealed that there are inadequate business education lecturers and staff with the requisite 21st century entrepreneurship skills. The staff include: lecturers, instructors, lecturers with entrepreneurship skills, instructors with entrepreneurship skills, lecturers who are ICT compliant, instructors who are ICT compliant, lab technicians, data analysts, and supporting staff. The finding of the study on the business staff is in congruity with Hodge and Lear (2011) who pointed out that academic staff with $21^{\text {st }}$ century skills can positively impact students with skills that can make them employable during their post-graduation and in this knowledge era economy. Again, the finding of the study on the poor 21st century entrepreneurship skills by the business education lecturers and staff was supported by AMA (2010); Fong, Sidhu, and Fook (2013) who pointed out that most academic staff in tertiary institutions lack the needed 21st century entrepreneurship skills needed in today's world of work particularly the use of media and technological tools. The finding of the study also agrees with the Partnership for 21st Century Skills (2006) survey cited by 
Hodge and Lear (2011) which revealed that many employers of labour lament that tertiary institutions are failing in their role to adequately developing needed skills for today's world of work in students.

Again, the finding of the study on the critical and creative thinking skills in business education programmes showed that the skills are not adequately taught and exposed to the students. The finding of the study validates AMA (2010) who pointed out those lecturers and students were of similar view that critical thinking/problem solving, creativity, and collaboration/teamwork are necessary skills required by students for post-graduate entry level employment. Similarly, the study supports Ruggiero (2003) who insisted that creative thinking is a great skill which every business education student require to develop new and imaginative ideas, concepts, plans, and other things that can make him/her a valued person and employable. It will also help the student to think "outside the box" and to solve real life and business problems.

The study on the adequacy of $21^{\text {st }}$ century technological equipment available for the teaching of business education programmes showed that some of the tertiary institutions have computers, internet and email facilities and also modem. However, the study revealed that modern technological equipment required in today's world of work are not adequately available. Some of the technological equipment include: cyber café, e-mail, virtual realities equipment, cloud computing facilities, teleconferencing equipment, internet facilities, uninterrupted power supply, printer, projector, scanner base, software packages, sealing machine, flash drive, Software packages (Apps) and social media, Internet of Things (Io T), iPod, and smartphone. The findings of the study on the $21^{\text {st }}$ technological facilities is in agreement with Forsberg (2017) who identified that virtual reality, iPod, smartphone, high definition and home theatre, digital media (ebooks, digital downloads, streaming, and more), apps, social media, high speed internet (broadband, Wi-Fi and 4g), the cloud, and the internet of things are $21^{\text {st }}$ century technologies that are needed for effective teaching of business education courses.

\section{Conclusions}

The level of exposure of entrepreneurship skills in business education programme for graduates of tertiary institutions in Taraba State, Nigeria is very low. This is as a result the nature of the business education curriculum and inability of the institutions in identifying the change in economic trend which should be reflected in the teaching and learning process of business education courses. There are several entrepreneurship skills needed by business education graduates for them to fit into today's world of work. Unfortunately, many problems are militating against the incorporation of the entrepreneurship skills in business education programmes particularly in tertiary institutions in Taraba State, Nigeria. Some of the problems are: most of the academic and technical staff who are meant to teach the business courses do not possess the $21^{\text {st }}$ century entrepreneurship skills such as innovation skills, critical and creative thinking skills, and technological skills. In addition, some of the modern and $21^{\text {st }}$ century technological equipment and tools are not adequately provided by the government to the tertiary institutions. Such equipment includes: virtual realities equipment, cloud computing facilities, teleconferencing equipment, internet facilities, cyber café, e-mail, uninterrupted power supply, printer, projector, scanner base, software packages, sealing machine, flash drive, software packages (Apps) and social media, Internet of Things (Io T), iPod, and smartphone among others. In view of these, it is therefore, imperative that the government, tertiary institutions and business education lecturers and other teaching staff to realize that except the students are adequately trained with the $21^{\text {st }}$ century skills, they will not be able to compete effectively in the labour market. This in turn will mean that the institutions are unfocused and unproductive.

\section{Policy Recommendations}

- Government should strive to infuse policies that are relevant for effective integration of entrepreneurship skills into the national policy on education.

- The business education curriculum should be reviewed and updated to include entrepreneurship skills both in content and pedagogy.

- Government and authorities of tertiary institutions in Nigeria should encourage, support and sponsor business education staff for professional development on the $21^{\text {st }}$ century entrepreneurship skills through regular workshops, seminars and conferences.

- Adequate funding of business education programme should be provided by government and other stakeholder's support.

- The government and other stakeholder should provide modern $21^{\text {st }}$ century technological facilities and equipment.

- Tertiary institutions and regulatory authorities should increase the campaign for the awareness of the derivable benefits of adequate exposure of entrepreneurship skills in business education programme for proper equipping of the students for the $21^{\text {st }}$ century world of work, and self-reliance.

\section{References}

i. The American Association of Colleges for Teacher Education, (AACTE) (2010). 21st century knowledge and skills in educator preparation Retrieved on March 3, 2019 from: https://files.eric.ed.gov/fulltext/ED519336.pdf

ii. Sherief, B. R. (2005). Entrepreneurship as an Economic Force in Rural Development. Retrieved 22/10/2012 from www.africaneconomicanalysis.org/articles/gen/ ruralentrepreneurship.htmil

iii. Ruggiero, V. R. (2003) Critical Thinking: Supplement to Becoming a Master Student. Rapid City, Michigan: Houghton Mifflin company. 
iv. Oosterbeek, H., Van Praag, M., \&Ijsselstein, A. (2010). The impact of entrepreneur-ship education on entrepreneurship skills and motivation. European Economic Review, 54(3), 442-454. doi:10.1016/j.euroecorev.2009.08.002.

v. National Bureau of statistic. [2018]. The premium Times, Nigeria.

vi. Morrison, K. (2010). 21st Century Skills for a 21st Century Economy. Retrieved on March 3, 2019 from: https://www.entrepreneur.com/article/218643

vii. Kuratka, D. F. \& Richard, M. H. (2001). Entrepreneurship. USA: Dryden press series in Entrepreneurship.

viii. Keylly, M. \& Norwood, J. (2011). Impact investing for Rural Wealth Creation: investing for financial Returns and Computing Impact. Boston, MA: Emerging Change Makers Network, Tellus Institute.

ix. Hodge, K. A. \&Lear, J. L. (2011). Employment skills for 21st century workplace: The gap between faculty and student perceptions. Journal of Career and Technical Education, 26(2) Faculty of business of education.

x. Forsberg, J. (2017). Top 10 Tech of the 21st Century (So far). Retrieved on March 5, 2019 from: https://www.axel.org/blog/top-10-technology-of-the-21st-century-so-far/

xi. Fong, L. L., Sidhu, G. K., \&Fook C. Y. (2013). Exploring 21st century skills among postgraduates in Malaysia. Procedia - Social and Behavioral Sciences 123, 130 - 138. doi: 10.1016/j.sbspro.2014.01.1406US

xii. E.B Azuka, B.O. NWOSU, I . N KOMU, E,E AGOMUO (2006).

xiii. Foundation s of Business Education in Nigeria.

xiv. E. C. Osudo (2009) Business and Computer Education, ChestonAgenly Limited Enugu, Nigeria.

xv. National Bureau of statistic. (2018). Thepremum Tines, Nigeria Retrieve March 8/2019.

xvi. AyubaAminu (2009). Entrepreneurship Theory and practice, compeq publishes Limited P.0 Box 8343 Maduguri. 